\title{
Contribution Analysis of "Suroboyo Bus" in Waste Management Based on Two Form of Complete Fourier Series Estimator
}

\author{
M. Fariz Fadillah Mardianto ${ }^{1 *}$, Reynaldy Aries Ariyanto ${ }^{2}$, Raka Andriawan ${ }^{3}$, \\ Devayanti Anugerahing Husada ${ }^{4}$ \\ 1,2,3,4 Department of Mathematics, Universitas Airlangga, Surabaya, Indonesia
}

Article history:

Received Nov 11, 2020

Revised May 24, 2021

Accepted Jun 11, 2021

Kata Kunci:

Estimator deret Fourier, Regresi Nonparametrik, Manajemen Limbah, Suroboyo Bus

Keywords:

Fourier series

estimator,

Nonparametric

Regression, Waste

Management,

Suroboyo Bus

\begin{abstract}
Abstrak. Sampah plastik merupakan permasalahan yang hampir ada di seluruh negara. Permasalahan ini muncul karena kurangnya fasilitas yang dapat menangani sampah plastik. Suroboyo Bus merupakan inovasi baru untuk masalah tersebut karena Suroboyo Bus menggunakan plastik botol sebagai alat pembayaran. Tujuan dari penelitian ini adalah untuk memprediksi persentase kontribusi Suroboyo Bus dalam penanganan sampah plastik. Estimator deret Fourier memiliki kinerja yang baik untuk pemodelan data dengan pola tren musiman. Penelitian ini membahas dua pendekatan seri Fourier. Perbedaan antara pendekatan tersebut adalah dimasukkannya fungsi phi $(\pi)$ ke dalam model. Hasil penelitian menunjukkan goodness of fit dengan fungsi $\pi$ sebesar 99,96\% untuk $\mathrm{R}^{2}$ dan $0,08 \%$ untuk MAPE sedangkan goodness of fit tanpa fungsi $\pi$ adalah $100 \%$ untuk $\mathrm{R}^{2}$ dan $0,07 \%$ untuk MAPE. Kesimpulannya model deret Fourier tanpa fungsi $\pi$ lebih baik karena model deret Fourier tanpa fungsi $\pi$ lebih memenuhi kriteria goodness of fit dibandingkan model deret Fourier dengan fungsi $\pi$.
\end{abstract}

\begin{abstract}
Plastic waste is a problem that almost exists in all countries. This problem arises because of the lack of facilities that can handle the plastic waste. Suroboyo Bus is an innovation for this problem because Suroboyo Bus uses plastic bottles as payment. The purpose of this research is to predict the percentage contribution of Suroboyo Bus in handling plastic waste. The Fourier series estimator performs well for data modeling with seasonal trend patterns. This paper examines two approaches to the Fourier series. The difference between the approaches is the inclusion of the phi $(\pi)$ function in the model. The result shows the goodness of fit criterion model with $\pi$ function are for and $0,08 \%$ for MAPE whereas the fit criterion model without $\pi$ function is $100 \%$ for and $0,07 \%$ for MAPE. In conclusion, the Fourier series model without the $\pi$ function is better because the Fourier series model without the $\pi$ function is more satisfy the goodness of fit criteria than the Fourier series model with the $\pi$.
\end{abstract}

How to cite:

M. F. F. Mardianto, R. A. Ariyanto, R. Andriawan, and D. A. Husada, "Contribution Analysis of "Suroboyo Bus" in Waste Management Based on Two Form of Complete Fourier Series Estimator”, J. Mat. Mantik, vol. 7, no. 1, pp. 86-95, May 2021.

CONTACT:

M. Fariz Fadillah Mardianto, $\boldsymbol{B}$ m.fariz.fadillah.m@fst.unair.ac.id $\boldsymbol{\Theta}$ Department of Mathematics, Universitas Airlangga, Surabaya 60115, Indonesia 

M. Fariz Fadillah Mardianto, R. Aries Ariyanto, Raka Andriawan, and Devayanti A. Husada, Contribution Analysis of "Suroboyo Bus" in Waste Management Based on Two Form of Complete Fourier

\section{Introduction}

The issue of waste treatment is a crucial problem. In 2016, total garbage in Indonesia was 65.200 .000 tons with population of 261.115 .456 people [1]. Population in Indonesia is predicted to increase over time and predicted to increase the amount of waste. According to the Central Bureau of Statistics Indonesia, the production of waste happens massively in town. Surabaya's city produces $9,896.78$ waste every day, and Jakarta's city produces $7.164,53$ volume of waste every day. If the waste problem is not solved, it will negatively affect water pollution, land, and air. Some of the effects of the waste problem in Indonesia are the average quality pollution with heavy iron, emission of greenhouse effect from waste in 2014, and 30,26\% to the emission of word greenhouse effect and it cause 1,805 floods in 2016-2017 [1]. Because of that, it is needed to reduce waste effectively. According to presidential decree number 97, released in 2017, Indonesia's government has the target to reduce waste by $30 \%$ and handle waste $70 \%$ from Indonesia's waste. It is still difficult because the amount of waste will increase in a row with an increase in Indonesia's population.

Waste management is matter that mentioned in SDGs for responsible consumption and production category. In order to increase waste management performance, one of the innovations that are applied is Suroboyo Bus. Suroboyo Bus is public transportation with a payment system using garbage. People can use the Suroboyo bus for 2 hours for every ride by exchange three plastic bottles of $1,5 \mathrm{~L}$ or five plastic bottles of $500 \mathrm{ml}$ or ten plastic glass of $240 \mathrm{ml}$. Department of Transportation says people who like the Suroboyo bus increase $15 \%$ every day and maximumly increase in the weekend. Surabaya's government says that Suroboyo Bus can reduce plastic waste in Surabaya and make Surabaya's people not littering. It is necessary to evaluate its function to solve the waste problem. Prior research has already reviewed the mechanism of Suroboyo Bus both as a means of public transportation and waste management effort [2]. Other previous research discusses the innovativeness and the implementation of the Suroboyo bus, which concludes that the Suroboyo bus is a good innovation as public transportation and its implementation is quite reasonable that positively accepted by the civilians [3]. However, until now, there is no further research of plastic waste management in Suroboyo Bus. As already mentioned, plastic waste is a means of payment used to enjoy this facility. In order to support the study of the Suroboyo bus, it should be research-related contributions to the Suroboyo bus in plastic waste management in Surabaya. The method to evaluate Suroboyo Bus is predicting the contribution of Suroboyo Bus. The contribution of Suroboyo Bus is measured as the total of waste loaded by Suroboyo Bus divided by estimated total waste production in Surabaya. Nonparametric regression with Fourier series estimation can be used to predict the contribution of the Suroboyo bus.

The regression model can be divided into three types: parametric, semiparametric, and nonparametric. The error term is assumed to follow specific distribution probabilities in parametric regression. This assumption is not required in nonparametric regression. Nonparametric regression uses a smoothing technique to obtain an estimate of the observation value. Because of that, nonparametric regression has high flexibility in approaching the pattern in data observation [4]. One of the methods in nonparametric regression is the Fourier series that uses the trigonometric function. A parameter, namely $\lambda$, determines the smoothing of the regression curve in the Fourier series. In general, nonparametric regression with Fourier series estimation is used in data with unknown patterns and has a seasonal trend.

This paper discusses two approaches to the Fourier series. The difference between those approaches is the inclusion of the phi $(\pi)$ function in the model. The performance of the models is tested and compared on a case study. Compare both of model Fourier 
series; it is used data contribution of Suroboyo Bus. The case study involves Suroboyo Bus, which accepts bottle plastic as payment. The goal of the study is to predict the percentage of Suroboyo Bus contribution to handling plastic waste. The best model of the Fourier series is determined with smaller MAPE and larger determination coefficient.

\section{Nonparametric Regression based on Fourier series Estimator}

\subsection{Estimator with phi ( $\pi)$ Function}

Fourier series is a trigonometric function which has show sine and cosine curve. Fourier series is best used on-trend seasonal data [5-8]. Based on Takezawa [5], a regression model for observation data $\left(t_{r}, y_{r}\right)$ can be written

$$
y_{r}=m\left(t_{r}\right)+\varepsilon_{r}, \quad r=1,2, \ldots, n
$$

Distribution of is normal with mean 0 and variant 1 . Assumed that $m\left(t_{r}\right) \in L_{2}$ [a,b] which is Hilbert's room, so that $m\left(t_{r}\right)$ can be stated as linear combination with the element base from $L_{2}[a, b]$. If $\left\{x_{j}\right\}_{j=1}^{\infty}$ is complete orthonomic system from $L_{2}[a, b]$ so $m\left(t_{r}\right)$ can be stated

$$
m\left(t_{r}\right)=\sum_{j=1}^{\infty} \beta_{j} x_{j}\left(t_{r}\right)
$$

According to Eubank [4], If $\beta_{j}$ is a scalar, then equation (1) became.

$$
y_{r}=\sum_{j=1}^{\infty} \beta_{j} x_{j}\left(t_{r}\right)
$$

Observation data is time function and periodic, then to estimate function equation (2) is used linear model which has sine function and cosine function [4]. Complex exponential function can be stated in sine function and cosine function. Complex exponential function can be written:

$$
x_{j}\left(t_{r}\right)=e^{2 \pi i j t_{r}}
$$

Substitution equation (4) to equation (2) and become as follows,

$$
\widehat{m}(t)=\sum_{j=-\lambda}^{\lambda} \hat{\beta}_{j} e^{2 \pi i j t_{r}}
$$

with $e^{i x}=\cos (x)+i \sin (x)$ and $e^{-i x}=\cos (x)-\sin (x)$ Fourier series estimator for $\widehat{m}\left(t_{r}\right)$ is as follows

$$
\begin{aligned}
\widehat{m}\left(t_{r}\right)= & \sum_{j=-\lambda}^{\lambda} \hat{\beta}_{j} e^{2 \pi i j t_{r}} \\
\widehat{m}\left(t_{r}\right)= & \sum_{j=-\lambda}^{\lambda} \hat{\beta}_{j} e^{2 \pi i j t_{r}}+\hat{\beta}_{(-j)} e^{2 \pi i(-j) t_{r}} \\
\widehat{m}\left(t_{r}\right)= & \hat{\beta}_{0}+\sum_{j=1}^{\lambda}\left(\hat{\beta}_{j} e^{2 \pi i j t_{r}}+\hat{\beta}_{(-j)} e^{2 \pi i(-j) t_{r}}\right) \\
\widehat{m}\left(t_{r}\right)= & \hat{\beta}_{0} \sum_{j=1}^{\lambda}\left[\hat{\beta}_{j}\left(\cos \left(2 \pi j t_{r}\right)+i \sin \left(2 \pi j t_{r}\right)\right)+\hat{\beta}_{(-j)}\left(\cos \left(2 \pi j t_{r}\right)-\right.\right. \\
& \left.\left.i \sin \left(2 \pi j t_{r}\right)\right)\right] \\
\widehat{m}\left(t_{r}\right)= & \hat{\beta}_{0}+\sum_{j=1}^{\lambda}\left[\left(\hat{\beta}_{j}+\hat{\beta}_{(-j)}\right) \cos \left(2 \pi j t_{r}\right)-i\left(\hat{\beta}_{j}+\hat{\beta}_{(-j)}\right) \sin \left(2 \pi j t_{r}\right)\right] \\
\widehat{m}\left(t_{r}\right)= & \hat{\beta}_{0}+\sum_{j=1}^{\lambda}\left[a_{j} \cos \left(2 \pi j t_{r}\right)+b_{j} \sin \left(2 \pi j t_{r}\right)\right]
\end{aligned}
$$

Where,

$$
\begin{aligned}
a_{j} & =\frac{2}{n} \sum_{r=1}^{n} y_{r} \cos \left(2 \pi t_{r}\right) \\
b_{j} & =\frac{2}{n} \sum_{r=1}^{n} y_{r} \sin \left(2 \pi t_{r}\right) \\
t_{r} & =\frac{t_{i}-1}{n}
\end{aligned}
$$


M. Fariz Fadillah Mardianto, R. Aries Ariyanto, Raka Andriawan, and Devayanti A. Husada, Contribution Analysis of "Suroboyo Bus" in Waste Management Based on Two Form of Complete Fourier

Subtitute equation (5) into equation (1) and become.

$$
y_{r}=\hat{\beta}_{0}+\sum_{j=1}^{\lambda}\left[a_{j} \cos \left(2 \pi t_{r}\right)+b_{j} \sin \left(2 \pi t_{r}\right)\right]+\varepsilon_{r}
$$

with estimator for regression curve is given as follows

$$
\hat{y}_{r}=\hat{\beta}_{0}+\sum_{j=1}^{\lambda}\left[\hat{a}_{j} \cos \left(2 \pi j t_{r}\right)+\hat{b}_{j} \sin \left(2 \pi j t_{r}\right)\right]
$$

\subsection{Estimator without phi $(\pi)$ Function}

In some conditions, the form of regression's curve can not be determined. It means some pattern can not be determined with some model of the parametric curve because it will produce high error and variance. If data assumed that the form of regression curve is unknown, it is suggested to use a nonparametric regression approach. Consider paired data, equation of nonparametric regression based on Mardianto et al., [7] given as follows:

$$
y_{i}=g\left(t_{i}\right)+\varepsilon_{i}
$$

With $y_{i}$ is respon variable, $t_{i}$ is predictor variable for nonparametric regression and $\varepsilon_{i}$ is error of model with normal distribution. Form of $g\left(t_{i}\right)$ function can not be determined and assumed with nonparametric regression function. Error of nonparametric regression assumed that identical, independent, and have normal distribution with 0 mean, and $\sigma^{2}$ varians [8].

If $g(t)$ is function which integrable and differentiable on interval $[\alpha, \alpha+2 \mathrm{~L}]$, so representation of Fourier series on that interval related with $g(t)$ that have trigonometric component sine and cosine given as follows :

$$
g(t)=\frac{a_{0}}{2}+\sum_{n=1}^{\infty}\left(a_{n} \cos \left(\lambda^{*} t\right)+b_{n} \sin \left(\lambda^{*} t\right)\right)
$$

where

$$
\lambda^{*} \approx \frac{n \pi}{L} ; n=1,2,3, \ldots
$$

As for Fourier coefficient determine with formula :

$$
\begin{aligned}
& a_{n}=\frac{1}{L} \int_{a}^{a+2 L} g(t) \cos \left(\lambda^{*} t\right) d t \\
& b_{n}=\frac{1}{L} \int_{a}^{a+2 L} g(t) \sin \left(\lambda^{*} t\right) d t
\end{aligned}
$$

If $g(t)$ is even function, so Fourier coefficient $b_{n}=0$. Therefore, the Fourier series is called cosine Fourier series. If $g(t)$ can be integrable and differentiable on interval $[0, \mathrm{~L}]$, so that cosine Fourier series can be written

where

$$
g(t)=\frac{a_{0}}{2}+\sum_{n=1}^{\infty} a_{n} \cos \left(\lambda^{*} t\right)
$$

$$
\lambda^{*} \approx \frac{n \pi}{L} ; n=1,2,3, \ldots
$$

According to Biederman et al., [9] for Fourier coefficient can be determined with formula:

$$
a_{0}=\frac{2}{L} \int_{0}^{L} g(t) d t: a_{n}=\frac{2}{L} \int_{0}^{L} g(t) \cos \left(\lambda^{*} t\right) d t
$$


If $g(t)$ is odd function, so Fourier coefficient $a_{n}=0$. Therefore the Fourier series called sine Fourier. If $g(t)$ integrable and differentiable on interval $[0, L]$, so sine Fourier series given as follows :

$$
g(t)=\frac{a_{0}}{2}+\sum_{n=1}^{\infty} b_{n} \sin \left(\lambda^{*} t\right)
$$

with

$$
\lambda^{*} \approx \frac{n \pi}{L} ; n=1,2,3, \ldots
$$

As for Fourier coefficient determine with formula :

$$
\begin{aligned}
& a_{0}=\frac{2}{L} \int_{0}^{L} g(t) d t \\
& b_{n}=\frac{2}{L} \int_{0}^{L} g(t) \sin \left(\lambda^{*} t\right) d t
\end{aligned}
$$

Because it has periodic formula and can approach trend data, Fourier series can be used in nonparametric regression curve. Based on Bilodeau [10], by adjustment Fourier series formula constructed Fourier series in equation (10) with add trend function

$$
g\left(t_{i}\right)=\frac{a_{0}}{2}+\omega t_{i}+\sum_{k=1}^{\lambda} a_{k} \cos \left(k t_{i}\right)+b_{k} \sin \left(k t_{i}\right)
$$

Therefore, equation of nonparametric regression approach with Fourier series estimator for paired data $\left(t_{i}, y_{i}\right)$ on equation (9) can be written as

$$
y_{i}=\frac{a_{0}}{2}+\omega t_{i}+\sum_{k=1}^{\lambda}\left(a_{k} \cos \left(k t_{i}\right)+b_{k} \sin \left(k t_{i}\right)\right)+\varepsilon_{i}
$$

with $a_{0}, \omega, a_{k}$ are regression parameters that, $k=1,2, \ldots, \lambda$ is oscillation parameter. Value of regression parameter estimator in vector form can be determined according to optimation method with Least Square (LS) approach.The estimation form for nonparametric regression can be obtained as follows:

$$
\hat{y}_{i}=\frac{\hat{a}_{0}}{2}+\widehat{\omega} t_{i}+\sum_{k=1}^{\lambda}\left(\hat{a}_{k} \cos \left(k t_{i}\right)+\hat{b}_{k} \sin \left(k t_{i}\right)\right)
$$

\subsection{Selection of Oscillation Parameters}

The selection of $\lambda$ values must be carried out optimally. Determination of optimal $\lambda$ can use Generalized Cross Validation (GCV) method. Based on $[15,16]$, formula of GCV can be written as follows:

$$
\operatorname{GCV}(\lambda)=\frac{\operatorname{MSE}(\lambda)}{\left(N^{-1} \operatorname{trace}(\boldsymbol{I}-\boldsymbol{A}(\lambda))\right)^{2}}
$$

where

$$
\operatorname{MSE}(\lambda)=N^{-1} \boldsymbol{y}^{T}(\boldsymbol{I}-\boldsymbol{A}(\lambda))^{T} \boldsymbol{W}(\boldsymbol{I}-\boldsymbol{A}(\lambda)) \boldsymbol{y}
$$

The GCV value depends on Mean Square Error (MSE) value because the numerator of GCV formula is the MSE formula. Measurement of goodness model is determined by the value of the determination coefficient $\left(\mathrm{R}^{2}\right)$ which shows the percentage contribution of the predictor variable to the response variable.

The best model that can be used for prediction needs to pass the goodness of criteria. The goodness of criteria is the smallest GCV value for an optimal oscillation 
M. Fariz Fadillah Mardianto, R. Aries Ariyanto, Raka Andriawan, and Devayanti A. Husada, Contribution Analysis of "Suroboyo Bus" in Waste Management Based on Two Form of Complete Fourier

parameter, the smallest MSE value, and the enormous determination coefficient value $[15,16]$.

\subsection{Measure of Goodness of Model}

The goodness of model can be measured by Mean Absolute Percentage Error (MAPE). MAPE is calculated using the absolute error in each period divided by the observed value that is evident for that period [13]. The formula of MAPE can be written:

$$
M A P E=\frac{\sum_{i=1}^{n} \frac{\left|Y_{i}-\bar{Y}_{i}\right|}{Y_{i}}}{n} \times 100 \%
$$

The goodness of model also can be measured by the determination coefficient $\left(\mathrm{R}^{2}\right)$. The determination coefficients determine how much influence between independent variable and dependent variable [19]. Formula of $\mathrm{R}^{2}$ can be written

$$
R^{2}=1-\frac{\sum_{i=1}^{n}\left(Y_{i}-\hat{Y}_{i}\right)^{2}}{\sum_{i=1}^{n}\left(Y_{i}-\bar{Y}\right)^{2}}
$$

\section{Research Method}

\subsection{Data Source}

Data collected from Surabaya government office that handling sanitary and green open space in Surabaya city. The obtained data is a time-series data of contribution of Suroboyo Bus in waste management measured as the total of waste loaded by Suroboyo Bus divided by estimated total waste production in Surabaya. The data start from May 1, 2018 to January 31, 2019. It uses data from 2018 as in sample and data from 2019 as out sample.

\subsection{Data Analysis Procedure}

The procedure in data analysis that is related to estimation contribution of Suroboyo bus with nonparametric regression used complete Fourier series estimator for both models from equation (7), and equation (19) was given as follows:

a. Study literature related to the contribution of Suroboyo bus and its relationship to the related predictor variables.

b. Perform descriptive statistics for each variable based on minimum, maximum, and average values.

c. Determine the GCV value for each model of nonparametric regression with Fourier series estimation that is used based on data.

d. Choose the smallest GCV value for every Fourier series used to determine oscillation parameter optimally, and calculate MAPE using equation (23) and calculate using equation (24).

e. Comparing two Fourier series estimators to determine the best model based on the smallest MAPE value and the largest $\mathrm{R}^{2}$.

\section{Result and Discussion}

Suroboyo Bus was public transportation with a payment system using garbage. Every day, from Suroboyo Bus payment system, waste is collected and distributed in a garbage bank. The contribution of Suroboyo Bus from May 1, 2018, until January 31, 2019, can be explained in Figure 1. 


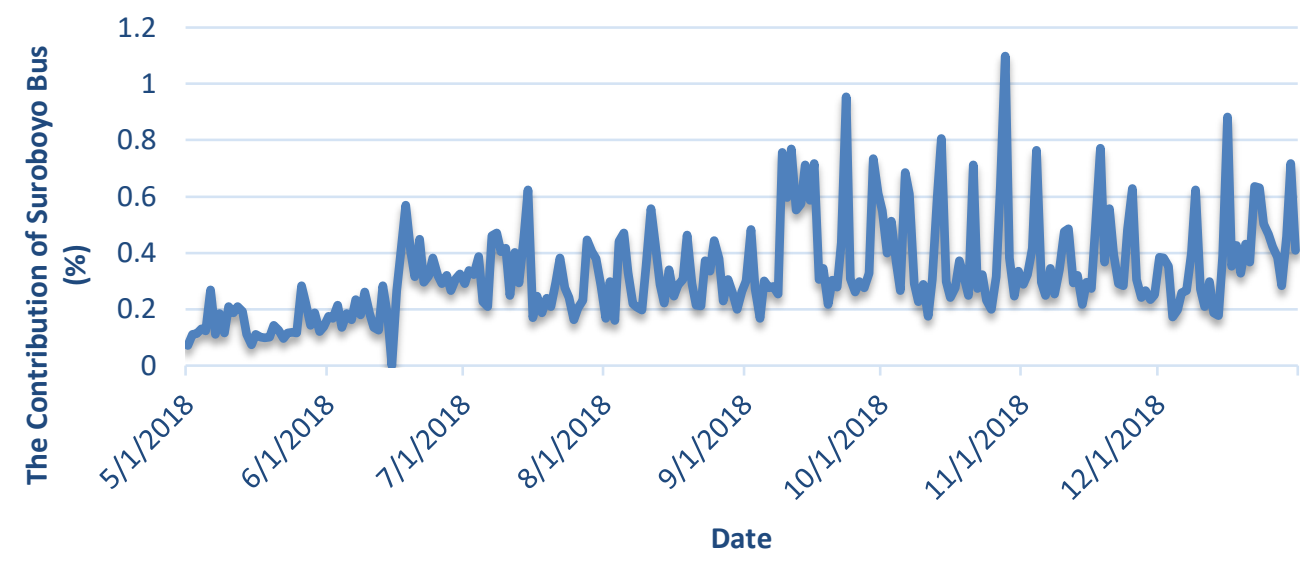

Figure 1. Graph of Contribution of Suroboyo Bus

From Figure 1, in May 2018 until December 2018, it increased slowly. The highest contribution of Suroboyo Bus in October 2018 with 1,1\%, and the lowest contribution in June 2018 with $0 \%$ (no operation). The data had an increased trend pattern and had a repetitive pattern. So, the data had a seasonal pattern, and the Fourier series estimator was suitable to estimate the contribution percentage of Suroboyo bus with nonparametric regression using the Fourier series estimator.

The results of the optimal GCV value that be calculated from $\mathrm{R}$ software used training data are presented in Table 1.

Table 1. GCV Value

\begin{tabular}{lcc}
\hline \multicolumn{1}{c}{ Model } & $\lambda$ & GCV \\
\hline With $\pi$ function & 38 & 0,01836 \\
Without $\pi$ function & 122 & $5,1994 \times 10^{-13}$ \\
\hline
\end{tabular}

Based on the result in Table 1, the minimum GCV value for nonparametric regression using Fourier series with $\pi$ function was 0,01836 with $\lambda$ equal to 38 was chosen. For nonparametric regression using the Fourier series without $\pi$ function, the minimum GCV value was $5,1994 \times 10^{-13}$ with equal to 122 was chosen. For nonparametric regression using Fourier estimation with $\pi$ model's, obtained model Fourier series in nonparametric regression as follows

$$
\begin{aligned}
\hat{y}_{i}= & \hat{\beta}_{0}+\hat{a}_{1} \cos \left(2 \pi t_{r}\right)+\hat{b}_{1} \sin \left(2 \pi t_{r}\right)+\cdots+\hat{a}_{38} \cos \left(76 \pi t_{r}\right)+ \\
& \hat{b}_{38} \sin \left(76 \pi t_{r}\right)
\end{aligned}
$$

where

$$
t_{r}=\frac{t_{i}-1}{n}
$$

Based on the results of, the parameter values in the nonparametric regression using Fourier series estimator with $\pi$ model's can be written as follows

$$
\begin{aligned}
\hat{y}_{i}= & 0,33079-0,05716 \cos \left(2 \pi t_{r}\right)-0,076012 \sin \left(2 \pi t_{r}\right)-\cdots- \\
& 0,02365 \sin \left(76 \pi t_{r}\right)
\end{aligned}
$$

For nonparametric regression using Fourier series without $\pi$, obtained model as follows: 
M. Fariz Fadillah Mardianto, R. Aries Ariyanto, Raka Andriawan, and Devayanti A. Husada, Contribution Analysis of "Suroboyo Bus" in Waste Management Based on Two Form of Complete Fourier

$$
\begin{aligned}
\hat{y}_{i}= & \frac{\hat{a}_{0}}{2}+\widehat{\omega} t_{i}+\hat{a}_{1} \cos \left(t_{i}\right)+\cdots+\hat{a}_{122} \cos \left(122 t_{i}\right)+\hat{b}_{1} \sin \left(t_{i}\right)+\cdots+ \\
& \hat{b}_{122} \sin \left(t_{i}\right)
\end{aligned}
$$

Based on the results, the parameter values in the nonparametric regression using Fourier series estimator without $\pi$ function model's can be written as follows

$$
\begin{aligned}
\hat{y}_{i}= & 0,40293-0,00115 t_{i}+0,001581 \cos \left(t_{i}\right)+\cdots+0,02863 \sin \left(t_{i}\right)+\cdots+ \\
& 0,0033 \sin \left(122 t_{i}\right)
\end{aligned}
$$

Figure 3 showed comparison between data estimation using Fourier series estimation without $\pi$ function, and data estimation using Fourier series estimation with $\pi$ function.

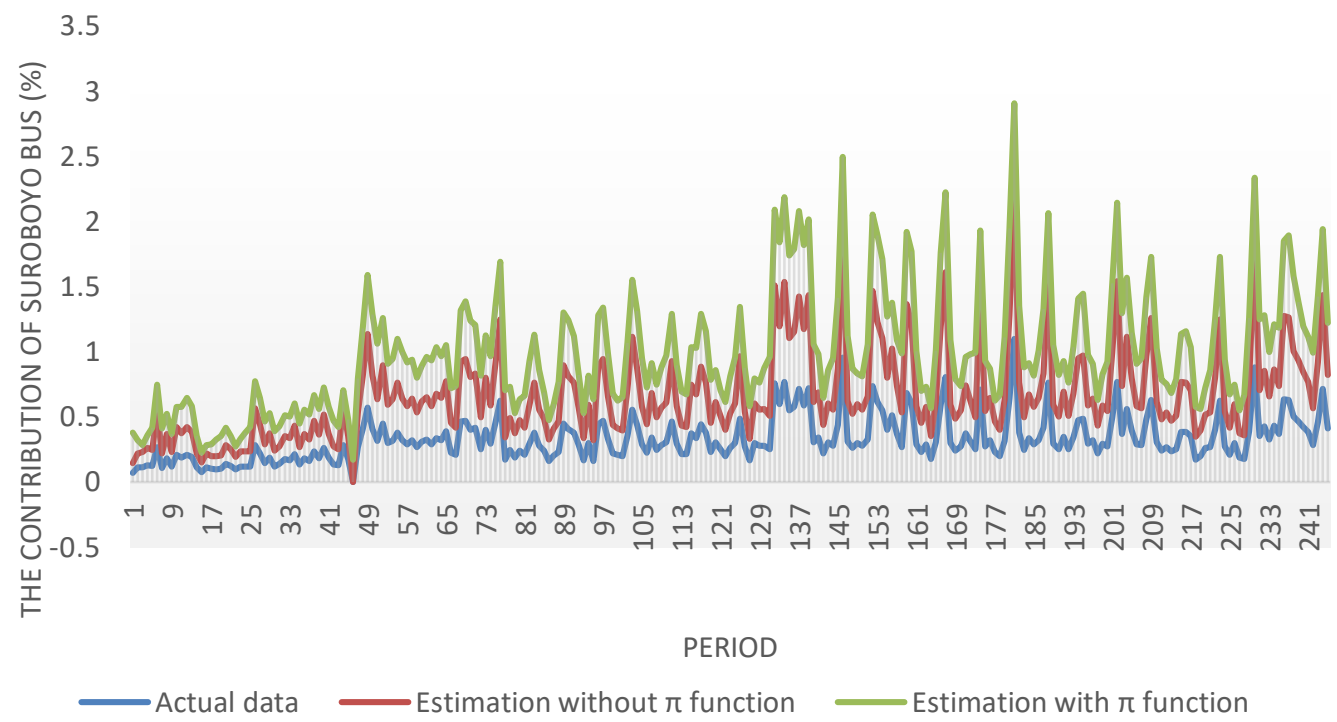

Figure 3. Graph of comparison between actual data and result

Based on Figure 3, estimation used Fourier series estimator without $\pi$ function closed to actual data than used Fourier series estimator with $\pi$ function. It means Fourier series estimator without $\pi$ function was better than Fourier series estimator with $\pi$ function for data because Fourier series estimator without $\pi$ function was smoother than Fourier series estimator with $\pi$ function. It was seen from graph for a model that closed to actual data. $\mathrm{R}^{2}$, and MAPE from Fourier series estimator with $\pi$ function in a row was $99,96 \%$ for $\mathrm{R}^{2}, 0,08 \%$ for MAPE. For Fourier series estimator without $\pi$ function, the result of $\mathrm{R}^{2}$, MAPE in a row was $100 \%$ for $\mathrm{R}^{2}$, and $0,07 \%$ for MAPE. Based on the result, Fourier series estimator without $\pi$ function was better than Fourier series estimator without $\pi$ function to estimate contribution percentage of Suroboyo bus because Fourier series estimator without $\pi$ functions was more flexible than Fourier series estimator with $\pi$ functions.

\section{Conclusions}

Suroboyo Bus had a chance to solve the plastic waste problem in a big city because the Suroboyo Bus can increase waste management percentage. From both models, Fourier series estimator without $\pi$ function was more suitable than Fourier series estimator with $\pi$ 
function because MAPE's Fourier series estimator without $\pi$ function was smaller than Fourier series estimator with $\pi$ function. Furthermore, determination coefficient's Fourier series estimator without $\pi$ function was higher than the Fourier series estimator with $\pi$ function. However, if we used the Fourier series estimator without $\pi$ function, it had an extended model because optimum $\lambda$ in the Fourier series estimator without $\pi$ function was equal to 122. This value was enormous, so it would difficult to interpret the model. Fourier series estimator with $\pi$ function was more parsimony than Fourier series estimator without $\pi$ function because optimum $\lambda$ in Fourier series estimator with $\pi$ function was smaller than Fourier series estimator without $\pi$ function.

There is still low research of Suroboyo Bus as a research object, especially about its ability to handle plastic bottle waste and waste management flow after the waste has been collected. Therefore, it is necessary to have further research to become input and feedback for related services, particularly the department of transportation and also Surabaya government office that handling sanitary and green open space in Surabaya city.

\section{References}

[1] Central Bureau of Statistic Indonesia and Ministry of Environment Indonesia, Environment Statistics of Indonesia, Jakarta: Central Bureau of Statistic, 2018

[2] Kurniawan, A.A., \& Prabawati, I, Implementasi Suroboyo Bus di Dinas Perhubungan Kota Surabaya. Publika Jurnal Ilmu Administrasi Negara, vol. 6, no. 9,2018

[3] Haqie, Z.A, Nadiah, R.E, Ariyani, O.P, Inovasi Pelayanan Publik Suroboyo Bis Di Kota Surabaya, Journal of Public Sector Innovations, Vol. 5, no. 1, pp.23-30, 2020

[4] Eubank, R.L, Nonparametric Regression and Spline Smoothing 2nd Edition, New York: Marcel Deker, 1998

[5] Takezawa, K, Introduction to Nonparametric Regression. John Wiley and Sons Inc. New Jersey, United State of America, 2006

[6] Hardle, W, Applied Nonparametric Regression, New York: Cambridge University Press, 1990

[7] Mardianto, M.F.F., Kartiko, S.H., \& Utami, H, Forecasting Trend-Seasonal Data Using Nonparametric Regression with Kernel and Fourier series Approach, Proceedings of the Third International Conference on Computing, Mathematics and Statistics (iCMS2017), pp. 343-349, 2019

[8] Suslov, S.K, An Introduction to Basic Fourier Series, Arizona: Springer Science, 2003

[9] Biedermann, S., Dette, H., \& Hoffmann, P, "Constrained Optimal Discrimination Designs for Fourier Regression Models", Ann Inst Stat Math Journal, vol. 61, no. 2, pp. 143-157, 2009

[10] Bilodeau, M, "Fourier Smoother and Additive Models". Canadian Journal of Statistics, vol. 20, no. 3, pp. 257-269, 1992

[11] Mardianto, M.F.F., Kartiko, S.H, Utami, H, Regression for Trend-Seasonal Longitudinal Data Pattern: Linear and Fourier Series Estimator, International Conference on Mathematics and Islam, vol. 1, pp. 350-356, 2018 
M. Fariz Fadillah Mardianto, R. Aries Ariyanto, Raka Andriawan, and Devayanti A. Husada, Contribution Analysis of "Suroboyo Bus" in Waste Management Based on Two Form of Complete Fourier

[12] Mardianto, M.F.F., Kartiko, S.H, Utami, H, Prediction the Number of Student in Indonesia who Study in Tutoring Agency and Their Motivations based on Fourier Series Estimator and Structural Equation Modelling, International Journal of Innovation, Creativity and Change (IJICC), vol. 5, no. 3, pp. 708-731, 2019

[13] Ulyah, S.M, Mardianto, M.F.F., Sediono, Comparing the Performance of Seasonal ARIMAX Model and Nonparametric Regression Model in Predicting Claim Reserve of Education Insurance. Journal of Physics: Conference Series 1397 012074, pp. 1-13, 2019

[14] Mardianto, M.F.F., Tjahjono, E, Rifada, M, Statistical Modelling for Prediction of Rice Production in Indonesia Using Semiparametric Regression Based on Three Forms of Fourier Series Estimator, ARPN Journal of Engineering and Applied Science, vol. 14, pp. 2763-70, 2019

[15] Mardianto, M.F.F., Tjahjono, E, Rifada, M, Semiparametric Regression Based On Three Forms Of Trigonometric Function In Fourier Series Estimator, Journal of Physics: Conference Series 1277012052 pp. 1-10, 2019

[16] Mardianto, M.F.F., Tjahjono, E, Syarifah, L, Andirani, P, Prediction of the Number of Foreign Tourist Arrival in Indonesia Halal Tourism Entrance using Simultaneously Fourier Series Estimator, KnE Social Sciences, pp. 1093-1104, 2019

[17] Mardianto, M.F.F, Semiparametric Regression Based On Fourier Series For Longitudinal Data With Weighted Least Square (WLS) Optimization, Journal of Physics: Conference Series 1836 012038, pp. 1-10, 2021

[18] Mardianto, M.F.F., Tjahjono, E, Rifada, M, Herawanto, A, Putra, A.L, Utama, K.A, The Prediction of Rice Production in Indonesia Provinces for Developing Sustainable Agriculture, Proceeding of the International Conference on Food and Agriculture,Vol.1.pp. 325-333, 2018

[19] Mardianto, M.F.F., Kartiko, H.S., \& Utami, H, The Fourier Series Estimator To Predict The Number Of Dengue And Malaria Sufferers In Indonesia, AIP Conference Proceedings 2329 060002, 2021

[20] Mardianto, M.F.F., Sediono, Safitri, S.A.D, Afifah, N, Syahzaqi, I, The Prediction of Indonesia Strategic Commodity Prices during the COVID-19 Pandemic based on a Simultaneous Comparison of Kernel and Fourier Series Estimator, Journal of Southwest Jiaotong University, Vol. 55, no. 6, pp.325-333, 2020 